\title{
IMPROVING STUDENTS ABILITY IN COUNTING MULTIPLE WITH THINGS AROUND ON MATH LESSON OF FOURTH GRADE STUDENTS IN ODD SEMESTER NO.33 GURUN PANJANG KECAMAATAN KOTO XI TARUSAN
}

\author{
AMRIL \\ Volume 1 Nomor 1 \\ JIPS ISSN: 2579-5449
}

\begin{abstract}
Low mastery of the ability to calculate multiplication in pe, the lesson is due to less precisely the model of learning and media used. So students become inactive, easily bored, and less attention to teacher explanations. Therefore to improve the multiplication counting ability Required model of learning with appropriate media. One of them is the model of learning by using the media objects nearby.

Based on the results of a daily test of mathematics lessons on multiplication multiplication shows that less successful learning. In the case according to the teacher's information in the daily learning has been explained orally, have been given examples, and even have been given the questions of practice and provide opportunities to students To ask, but they did not take advantage of the opportunity. This study aims to improve the ability to calculate multiplication fourth grade students of the first semester of S D Foreign N o. 33 Long Desert Sub Koto XI Tarusan.

South Coastal District with total students 49 children, 25 children and 24 children Students daughter male student. The data in this study were obtained from interviews, questionnaires, observation results of action, and evaluation results. This study was conducted in two cycles. Each cycle is done based on the stages:

Prepare an action plan, Implement action, Observation, and Analysis followed by reflection.

The results showed that according to the results of observations of researchers on preaction is in students less active learning, easy to saturate, and pay attention to students on teacher explanation is very small. In the first cycle- 1 of the mastery of the material before the learning is given $31 \%$, after the activity takes place students activeness shows: active students $58 \%$, students are $30 \%$, and $12 \%$ passive students. Student cooperation: active students $62 \%$, students are $28 \%$, and passive students $10 \%$. While the result of average evaluation 68 with students complete 33 students and not complete 16 students.Hasi 12 action in cycle action sebelun material penguasan $48 \%$. After the action is done student activity: active students $78 \%$, students are $18 \%$ and $4 \%$ passive students. Student cooperation: active students $84 \%$, students are $14 \%$, and $2 \%$ passive students. Evaluation result Average 76 students complete 46 complete students and 3 students not yet completed. Based on the above results kan It can be concluded that learning with the nearest media objects can improve the ability to calculate multiplication, increase student activity, and increase student cooperation in completing group tasks. Learning becomes enabling so students are not easily saturated.
\end{abstract}




\title{
PENINGKATAN KEMAMPUAN MENGHITUNG PERKALIAN DENGAN MEDIA BENDA-BENDA TERDEKAT PADA MATA PELAJARAN MATEMATIKA SISWA KELAS IV SEMESTER GANJIL SD NEGERI NO. 33 GURUN PANJANG KECAMAATAN KOTO XI TARUSAN
}

\begin{abstract}
ABSTRAK
Rendahnya penguasaan kemampuan menghitung perkalian dalam pe,belajaran tersebut dikarenakan kurang tepatnya model pembelajaran dan media yang digunakannya. Sehingga siswa menjadi tidak aktif, mudah bosan, dan kurang memperhatikan penjelasan guru. Oleh karena itu untuk meningkatkan kemampuan menghitung perkalian diperlukan model pembelajaran dengan media yang tepat. Salah satunya adalah model pembelajaran dengan menggunakan media benda-benda terdekat.

Berdasarkan hasil ulangan harian pelajaran matematika tentang perkalian bersusun menunjukkan bahwa pembelajaran kurang berhasil. Pada hal menurut informasi guru tersebut dalam pembelajaran sehari-hari sudah dijelaskan secara lisan, sudah diberi contohcontoh, dan bahkan sudah diberai soal-soal latihan dan memberi kesempatan pada siswa untuk bertanya, namun mereka tak memanfaatkan kesempatan tersebut. Penelitian ini bertujuan untuk meningkatkan kemampuan menghitung perkalian siswa kelas IV semester ganjil SD Negeri No. 33 Gurun Panjang Kecamatan Koto XI Tarusan .

Kabupaten Pesisir Selatan dengan Jumlah siswa 49 anak, 25 anak Siswa putri dan 24 anak siswa putra. Data dalam penelitian ini diperoleh dari hasil wawancara,angket, hasil observasi tindakan, dan hasil evaluasi. Penelitian

dilakukan berdasar tahapan: Menyusun rencana kegiatan, Melaksanakan tindakan, Observasi, dan Analisis yang dilanjutkan dengan refleksi.

Hasil penelitian menunjukkan bahwa menurut hasil observasi peneliti pada pra tindakan adalah dalam pembelajaran siswa kurang aktif, mudah jenuh, dan perhatin siswa pada penjelasan guru sangat kecil. Pada tindakan siklus-1 penguasaan materi sebelum pembelajaran diberikan $31 \%$, setelah kegiatan berlangsung aktivitan siswa menunjukkan: siswa aktif $58 \%$, siswa sedang $30 \%$, dan siswa pasif $12 \%$. Kerja sama siswa: siswa aktif $62 \%$, siswa sedang $28 \%$, dan siswa pasif $10 \%$. Sedangkan hasil evaluasi rata-rata 68 dengan siswa tuntas 33 siswa dan belum tuntas 16 siswa. Hasil tindakan pada siklus-2 penguasan materi sebelun tindakan $48 \%$. Setelah tindakan dilakukan aktivitas siswa: siswa aktif78\%, siswa sedang $18 \%$ dan siswa pasif $4 \%$. Kerja sama siswa: siswa aktif $84 \%$, siswa sedang $14 \%$, dan siswa pasif $2 \%$. Hasil evaluasi rata-rata 76 dengan siswa tuntas 46 siswa tuntas dan 3 siswa belum tuntas. Berdasarkan hasil penelitian di atas dapat disimpulkan bahwa pembelajaran dengan media benda-benda terdekat dapat meningkatkan kemampuan menghitung perkalian, meningkiatkan aktivitas siswa,dan meningkatkan kerja sama siswa dalam menyelesaikan tugas kelompok. Pembelajaran menjadi menyengankan sehingga siswa tak mudah jenuh.
\end{abstract} ini dilaksanakan dalam dua siklus. Setiap siklus 
Journal Ilmiah Pendidikan Scholastic

\section{Kata Kunci: perkalian, media benda-benda terdekat}

\section{PENDAHULUAN}

Latar Belakang Masalah, Secara umum matematika merupakan pelajaran yang dianggap sulit dan tidak disukai oleh siswa. Hal ini sesuai dengan hasil angket siswa kelas IV SD Negeri No. 33 Gurun Panjang Kecamatan Koto XI Tarusan yang menyatakan bahwa $45 \%$ siswa tidak menyukai pelajaran matematika dan merasa sulit untuk mengikutinya. Oleh karena itu hasil pembelajaran matematika tidak sesuai dengan yang diharapkan. Bahkan Mulyana (2001) dalam kata pengantarnya menyatakan bahwa nilai matematika berada pada posisi yang paling bawah, sehingga tidak heran kalau nilai matematika dipakai sebagai tolak ukur dari kecerdasan siswa.

Kalau kita kaji lebih dalam hal tersebut bukan merupakan kesalahan siswa semata tetapi dapat juga disebabkan oleh faktor guru itu sendiri sebagai pendidik .Kekurangan guru yang biasa dilakukan dalam kegiatan belajar mengajar adalah mengambil jalan pintas dalam pembelajaran, memberi hukuman tanpa melihat lataar belakang kesalahan, menunggu siswa berbuat salah, mengabaikan perbedaan siswa, merasa paling pandai, tidak adil, memaksa hak siswa, (Mulyasa, 2005:20).

Namun menurut hasil pengamatan peneliti kesalahan yang biasa dilakukan guru dalam membelajarkan matematika di tempat peneliti hingga siswa cepat menjadi bosan adalah: 1) Dalam membelajarkan matematika guru hanya berpedoman pada buku pegangan. 2) Penyampaian konsep sarat dengan hafalanhafalan. 3) Kegiatan pembelajaran masih monoton. 4) Kurang memperhatikan keterampilan prasarat.

Keterampilan prasarat memang sangat diperlukan dalam pembelajaran, hal tersebut seperti yang dikemukakan oeh Gagne (dalam Degeng:1997:4) bahwa setiap mata pelajaran mempunyai prasarat belajar (learning prerequisites). Dalam hubungannya dengan pembelajaran matematika maka keterampilan prasarat yang harus dikuasai siswa umumnya adalah hitung dasar yang meliputi: penjumlahan, pengurangan, perkalian, dan pembagian.

Sebaik apapun konsep matematika yang disampaikan oleh guru pada pembelajaran matematika namun bila siswa tidak menguasai hitung dasar sebagai keterampilan prasaratnya maka hasil pembelajaran kurang memuaskan. Berdasarkan hasil ulangan harian siswa kelas IV SD Negeri No. 33 Gurun Panjang Kecamatan Koto XI Tarusan semester ganjil tentang perkalian bersusun menunjukkan bahwa 20\% siswa menguasai secara tuntas, $35 \%$ siswa agak menguasai,dan $45 \%$ kurang menguasai pada hal pada pembelajaran matematika sehari-hari guru sudah menjelaskan secara lisan, ditulis di papan tulis, memberi contoh, bahkan memberikan soalsoal latihan tentang perkalian bersusun, dan juga siswa sudah diberi kesempatan untuk bertanya ketika guru mengajar, namun sedikit sekali mereka yang mengajukan pertanyaan.

Ketika guru balik bertanya hanya beberapa siswa yang dapat menjawab pertanyaan guru dengan benar, itupun karena siswa tersebut memang pandai di kelasnya. Dan bila diberi tes perkalian rata-rata hasilnya rendah. Rendahnya penguasaan kemampuan hitung perkalian kemungkinan besar dikarenakan guru kurang tepat dalam memilih cara atau media dalam pembelajaraan. Siswa kelas IV cara berfikirnya masih pada benda konkrit, sementara guru tidak memperhatikan hal tersebut sehingga dimungkan siswa mengalami kesulitan.

Berdasarkan masalah di atas peneliti akan berupaya meningkatkan kemampuan menghitung perkalai dengan media benda-benda sekitar yang dekat dengan siswa antara lain dengan jari tangan dan kartu bilangan. Dengan menggunakan media tersebut diharapkan siswa dapat meningkatkan kemampuan hitung perkalian, lebih baktif, kreatif sehingga lebih banyak siswa yang mencapai ketuntasan dalam 


\section{Journal Ilmiah Pendidikan Scholastic}

hafalan perkalian sampai bilangan 100, perkalian bersusun dan operasi perkalian.

Berdasarkan uraian di atas maka penelitian ini ditekankan pada peningkatan kemampuan menghitung perkalian dengan media benda-benda terdekat pada pelajaran matematikan sisqa kelas IV SD Negeri No. 33 Gurun Panjang Kecamatan Koto XI Tarusan. Dengan demikian dapat dirumuskan permasalahan sebagaai berikut: "Bagaimana menggunakan media benda-benda terdekat dapat meningkatkan kemampuan menghitung siswa kelas IV SD Negeri No. 33 Gurun Panjang Kecamatan Koto XI Tarusan?".

Sesuai dengan pernyataan peneliti yang telah dirumuskan, tujuan yang ingin dicapai dalam penelitian ini adalah meningkatkan kemampuan menghitung perkalian siswa kelas IV SD Negeri No. 33 Gurun Panjang Kecamatan
Koto XI Tarusan, dengan menggunakan media benda-benda terdekat.

\section{1) Perkalian denfan Faktor 11 Sampai dengan 100}

Pada dasarnya perkalian denjgan faktor $11 \mathrm{~s} / \mathrm{d}$ 100 ini mempunyai kesamaan dengan perkalian dengan faktor $6 \mathrm{~s} / \mathrm{d} 10$. Adapun perbedaanya pertama adalah pada perkalian dengan faktor 11 s/d 100 jari yang masih terlipat dikatan pasif artinya tak dihitung, dan yang berdiri dikatakan aktif, berarti pada perkalian factor ini yang dihitung hanya jari yang berdiri.

Adapun ketentuannya adalah jarin yang berdiri masing-masing bernilai 10 ( sesuai faktor ) dan pada jari yang berdiri itu pula bernilai satuan masing-masing dikalikan . kemudian hasilnya dijumlahkan. Perbedaan yang ke dua adalah pada perkalian factor 11s/d 100 ini terdapat sistem simpanan sebagai berikut:

\begin{tabular}{|c|c|c|}
\hline No. & Faktor Perkalian & Simpanan \\
\hline 1. & $11 \mathrm{~s} / \mathrm{d} 15$ & 100 \\
2. & $16 \mathrm{~s} / \mathrm{d} 20$ & 200 \\
3. & $21 \mathrm{~s} / \mathrm{d} 25$ & 400 \\
4. & $26 \mathrm{~s} / \mathrm{d} 30$ & 600 \\
5. & $31 \mathrm{~s} / \mathrm{d} 35$ & 900 \\
6. & $36 \mathrm{~s} / \mathrm{d} 40$ & 1200 \\
7. & $41 \mathrm{~s} / \mathrm{d} 45$ & 1600 \\
8. & $46 \mathrm{~s} / \mathrm{d} 50$ & 2000 \\
9. & $51 \mathrm{~s} / \mathrm{d} 55$ & 2500 \\
10. & $56 \mathrm{~s} / \mathrm{d} 60$ & 3000 \\
11. & $61 \mathrm{~s} / \mathrm{d} 65$ & 3600 \\
12. & $66 \mathrm{~s} / \mathrm{d} 70$ & 4200 \\
13. & $71 \mathrm{~s} / \mathrm{d} 75$ & 4900 \\
14. & $76 \mathrm{~s} / \mathrm{d} 80$ & 5600 \\
15. & $81 \mathrm{~s} / \mathrm{d} 85$ & 7200 \\
16. & $86 \mathrm{~s} / \mathrm{d} 90$ & 8100 \\
17. & $91 \mathrm{~s} / \mathrm{d} 95$ & 9000 \\
18. & $96 \mathrm{~s} / \mathrm{d} 100$ & \\
& & \\
\hline
\end{tabular}

Penerapan pada perkalian pada faktor 11 sampai dengan 100

\begin{tabular}{|l|l|l|l|}
\hline No. & Perkalian & \multicolumn{1}{|c|}{ Peragaan } & \multicolumn{1}{|c|}{ hasil } \\
\hline 1. & $12 \times 12$ & & $100+(4 \times 10)+(2 \times 2)$ \\
& & & $100+40+4$ \\
2. & $16 \times 17$ & & 144 \\
& & & $200+(3 \times 10)+(6 \times 7)$ \\
\hline
\end{tabular}




\begin{tabular}{|c|c|c|}
\hline & & $\begin{array}{l}200+30+42 \\
272\end{array}$ \\
\hline 3. & $22 \times 24$ & $\begin{array}{l}400+(6 \times 20)+(2 \times 4) \\
400+120+8 \\
528\end{array}$ \\
\hline 4. & $37 \times 38$ & $\begin{array}{l}1200+(5 \times 30)+(7 \times 8) \\
1200+150+56 \\
1406\end{array}$ \\
\hline 5. & $41 \times 43$ & $\begin{array}{l}1600+(4 \times 40)+(1 \times 3) \\
1600+160+3 \\
1763\end{array}$ \\
\hline
\end{tabular}

\section{METODE PENELITIAN}

Berdasarkan pada latar belakang penelitian, maka pendekatan penelitian ini adalah Pendekatan penelitian kualitatif. Pendekatan kualitatif mempunyai karakteristik sebagaimana dilakukan oleh Sugiano, (dalam Harmini:2004:21) antara lain : 1) Kondisi objek alamiah, 2) Peneliti sebagai objek utama, 3) Kaya akan data yang bersifat deskriptif keadaan, 4) Analisis dilakukan secara induktif (dari contoh ke kesimpulan atau dari khusus ke umum) dan berlangsung sejak dimulai sampai pengumpulan data selesai, 5) Pengumpulan data dilakukan secara simultan atau berkesinambungan, baik dalam hal metode, sumber, dan pengumpulan data.

Pendekatan kualitatif dalam penelitian ini digunakan untuk menelusuri dan mendapatkan gambaran secara jelas tentang fenomena yang tampak selama pembelajaran berlangsung. Fenomena yang dimaksud adalah situasi kelas dan tingkah laku siswa selama proses pembelajaran berlangsung.

Penelitian ini merupakan penelitian tindakan kelas (action reseach) karena penelitian ini dilakukan untuk memecahkan masalah di kelasdan dilakukan sesuai dengan langkah langkah pada penelitian tindakan kelas. Penelitian tindakan kelas dilakukan dengan diawali oleh suatu kajian terhadap suatu masalah secara sistematis. Hasil kajian digunakan sebagai dasar untuk mengatasi masalah .Dalam proses perencanaan yang telah disusun dilakukan observasi dan evaluasi dan hasilnya difahami sebagaai masukan untuk melakukan refleksi atas apa yang terjadi pada tahapan perencanaan.

Tahapan-tahapan di atas dilakukan berulang-ulang dan bersinambungan sampai suatu kualitas keberhasilan tertentu dapat tercapai, Wibawa (2004:4). Dalam penelitian ini guru bekerjasama dengan mitra kalaborasi yaitu guru kelas IV dan teman sejawat. Hal ini dimaksudkan agar konsentrasi guru dalam mengajar tidak terbelah oleh hal-hal lain. Dengan cara ini diharapkan akan didapatkan data yang seobjetif mungkin demi kefalidan data yang diperlukan.

Penelitian ini dilakukan di SD Negeri No. 33 Gurun Panjang Kecamatan Koto XI Tarusan. Alasan pemilihan lokasi ini adalah peneliti mengajara di SD tersebut dan lokasi SD ini berada di tengah kota Kecamatan Koto XI Tarusan. Penelitian ini dilaksanakan mulai September sampai bulan November 2016 semester ganjil, pada siswa kelas IV SD Negeri No. 33 Gurun Panjang Kecamatan Koto XI Tarusan dengan jumlah siswa 39.

Data yang diperoleh diambil dari hasil kegiatan yang berhubungan dengan pembelajaran matematika hitung perkalian dan pembagian pada siswa kelas IV SD Neger "'r 33 Gurun Panjang Kecamatan Koto XI Tar Adapun data yang diperoleh dalam peneliti: 
adalah: 1) Data dari angket siswa, pengamatan peneliti terhadap hasil pembelajaran matematika, dan dari hasil wawancara peneliti dengan guru kelas IV. 2) Dari hasil catatan perilaku siswa selama pembelajaran berlangsung. 3) Dari hasil belajar siswa melalui tes yang dilakukan selama proses pembelajaran perkalian dan pembagian. 4) Prosedur Pengumpulan Data

Prosedur pengumpulan data dilakukan berdasarkan bentuk data yang ingin diperoleh. Untuk mengetahui kemampuan menghitung perkalian dilakukan dengan tes hasil belajar dalam bentuk skor. Sedangkan data tentang sikap dan perilaku serta tanggapan siswa selama pembelajaran perkalian dilakukan melalui pengamatan pada subjek penelitian.
Data mengenai pelaksanaan pembelajaran dalam kelas diperoleh melalui catatan lapangan dan wawancara. Oleh karena itu peneliti mempunyai tugas rangkap yaitu sambil mengajar guru juga mengumpulkan data. Maka untuk memperoleh data yang akurat, dalam mendapatkan data guru bekerja sama dengan guru kelas IV dan teman sejawat untuk melakukan pengamatan.

Selanjutnya dari hasil pengamatan didiskusikan bersama. Hasil dari diskusi akan digunakan sebagai pedoman untuk menentukan refleksi dalam melakukan tindakan selanjutnya. Pemberian tindakan ini dilakukan berulang-ulang (siklus) agar dapat diambil kesimpulan yang sesuai dengan fokus penelitian.

\section{Analisis Data}

Memperhatikan jenis data yang dikumpulkan, ada dua teknik yang digunakan dalam penelitian ini yaitu analisis kualitatif dan analisis kuantitatif. Analisis kuantitatif digunakan terhadap hasil tes sedangkan analisis kualitatif digunakan dalam data kualitatif yang diperoleh dari hasil pengamatan terhadap guru, siswa, atau hal-ahal lain yang tampak selama penelitian ini. Demikian juga aktivitas dan kerja sama dengan kelompok dalam pembelajaran juga didasarkan pada indikator yang muncul.

Kemudian dari hasil catatan lapangan yang dilengkapi dengan hasil observasi, wawancara dan dari hasil angket siswa dilakukan analisis bersama guru kelas IV dan teman sejawat, kemudian ditafsirkan berdasarkan kajian pustaka dan pengalaman guru. Sedangkan kemampuan menghitung perkalian dianalisis berdasarkan rata-rata perolehan.

Pembelajaran hitung perkalian dianggap tuntas bila perolehan hasil evaluasi siswa ratarata hasil hitungan $>70$, dan siswa dianggap tuntas dalam penguasaan hitung perkalian bila memperoleh nilai baik yaitu 70 .

\section{Keterangan :}

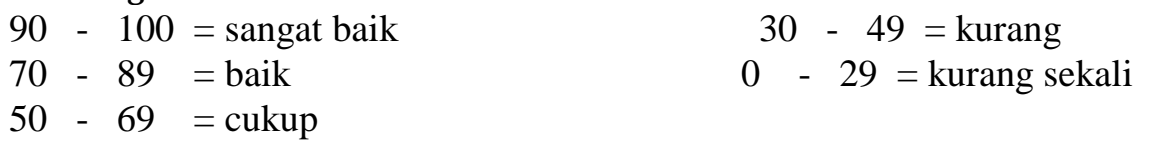

\section{Rancangan Penelitian}

Penelitian tindakan kelas ini dilakukan dalam dua suklus kegiatan yaitu siklus- 1 dan siklus- 2, masing-masing siklus terdiri atas empat tahap dan dilakuan dalan satu pertemuan. Hal ini dilakukan karena terbatasnya waktu yang tersedia. Tahapan kegiatan setiap siklus adalah: 1) Menyusun rencana kegiatan, 2) Melakukan

tindakan, 3) Melakukan observasi, dan 4) Membuat analisis yang di lanjutkan dengan refleksi.

Pada penelitian ini yang melaksanakan kegiatan mengajar adalah peneliti, sedangkan yang bertindak sebagai observer adalah guru kelas IV dibantu oleh teman sejawat.

B. Siklus -1

1. Penyusunan Rencana Kegiatan 


\section{Journal Ilmiah Pendidikan Scholastic}

Pada tahap ini guru menysun rencana pembelajaran berdasar pokok bahasan yang akan diajarkan yaitu menghafal perkalian sampai bilangan 100, dengan urutan:

a) Menyiapkan peralatan pembelajaaran.

b) Menyusun silabus.

c) Menyusun rencana pembelajaran.

d) Menyusun instrumen yang terdiri atas:

(1) Lembar pengamatan aktivitan dan koopertif siswa.

(2) Lembar pengamatan untuk guru.

(3) Soal evaluasi.

(4) Menentukan jadwal tindakan kelas.

2. Pemberian Tindakan

1) Sebagai penjajagan guru memberikan pertanyan kepada siswa.tentang perkalian.

2) Guru memberikan apersepsi tentang pentingnya kemampuan menghitung perkalian.

3) Guru mengajak siswa untuk bermain lompat jari, mulai dari lompat dua-dua sampai dengan lompat sepuluh. Siswa yang sudah mampu memperagakan ke depan kelas.

4) Menerapkan permainan pada perkalian dengan mengulang kembali pertanyaan pada penjajagan, siswa yang dapat mengacungkan tangan kemudian menyebutkan jawabab dengan pemaparan, kemudian dikuatkan dengan penjelasan singkat dari guru.

5) Siswa dibentuk dalam kelompok. Tiap kelompok menerima kartu bilangan, kemudian kartu-kartu terswbut dipasang-pasangkan hingga membentuk perkalian dan ditulis pada lembar kerja untuk didelesaikan bersama.

6) Siswa melaporkan hasil kerja kelompok dengan menuliskan pada papan tulis. Sedang kelompok yang lain mengoreksi hasil kerja kelompok yang lain.

7) Sebagai penguat guru memberikan pertanyaan secara lisan

8) Evaluasi.

3. Melakukan Observasi

Pada saat kegiatan pembelajaran berlangsung guru kelas IV sebagai observer beserta teman sejawat melakukan pengamatan dan mencatat kejadian - kejadian selama

pembelajaran berlangsung. Hasil catatan observasi bermanfaat untuk pengambila keputusan dalam kegiataan selanjutnya yaitu refleksi.

\section{Refleksi}

Dari hasil pengamatan yang dilakukan peneliti sebagai guru, hasil pengamatan guru kelas IV, dan pengamatan teman sejawat dikumpulkan dan dibahas bersama untuk mendapatkan kesamaan pandangan terhadap tindakan awal pada siklus pertama.Hasil diskusi

Tindakan II ini dilakukan berdasar masalah yang masih ada pada siklus - 1 . Tindakan lebih ditekankan pada aktifitas, kerja sama, dan kemampuan menghitung perkalian bersusun. Pelaksanaan Observasi

Pada saat guru mengajar guru kelas IV bersama teman sejawat melakukan pengamatan sebagaimana yang dilakukan pada siklus -1 .

tersebut akan dijadikan bahan untuk menentukan langkah tindakan selanjutnya pada siklus ke -2 . Rencana kegiatan disusun berdasar hasil analisis dan reflesi selama siklus -1 . Topik yang dibahas pada siklus -2 ini adalah perkalian bersusun. Pemberian Tindakan

Pada akhir tindakan II dilakukan analisis dan refleksi terhadap kegiatan yang telah dilakukan. Dan hasil dari analisis dan reflek ${ }^{\sim}$ :-.: disusun kesimpulan dan saran dari se 140 kegiatan pada siklus -2 . 


\section{HASIL PENELITIAN DAN PEMBAHASAN}

Pada kegiatan ini diawali dengan paparan data pra tindakan. Paparan data ini diperoleh dari hasil observasi peneliti pada pembelajaran matematika yang disajikan oleh guru kelas IV pada tanggal 12 September 2016. Hal ini dilakukan oleh peneliti agar mengetahui lebih dekat karakteristik siwa kelas IV dan model pembelajaran matemataika pada kelas tersebut. Dalam penyajian tersebut materi pokok yang dibahas adalah melakukan penaksiran dan pembulatan dengan indicator membulatkan hasil operasi hitung dalam satuan, puluhan, dan ratusan.

Penyajian diawali dengan guru memerintahkan siswa untuk membuka buku matematika pada halaman yang sesuai dengan pembahasan. Kemudian guru memberi contoh cara membulatkan hasil operasi hitung. Selanjutnya guru memberi kesempatan pada siswa untuk bertanya, setelah tidak ada yang bertanya guru memberikan soal pembulatan secara lisan; "Dalam pembulatan puluha, 72 dibulatkan menjadi berapa anak-anak?" tanya guru, " Coba yang dapat angkat tangan !" Beberapa anak mengangkat tangan dan rata-rata jawaban mereka benar.

Setelah dianggap dapat guru memerintahkan siswa untuk menyelesaikan soalsoal pada halaman yang sudah ditentukan. Pada penyajian ini tampak siswa kurang semangat, beberapa anak kurang memeperhatikan penjelasan guru, bahkan ada yang sibuk bermain sendiri. Ketika diberi kesempatan untuk bertanya tidak ada yang bertanya. Begitu juga ketika menyelesaikan soal banyak siswa yang menggantungkan diri pada teman sebangku. Suasana tampak sunyi karena sudah diberi tahu oleh guru bahwa yang ramai akan berdiri di depan kelas.

Setelah selesai hasil pekerjaan siswa dikoreksi oleh guru, siswa secara bergantian menuliskan jawabannya kedepan. Suasana mulai ramai, berkali-kali guru mengingatkan siswa agar tidak ramai. Dari hasil koreksi guru banyak pekerjaan siswa yang salah. Hal ini tidak sesuai dengan saat guru bertanya pada penjelasan tadi yang rata-rata siswa mampu menjawab. Guru mulai jengkel, penjelasan diulang kembali, siswa diam tak berani berbuat apa-apa. Suasana yang demikian dikarenakan guru melupakan keterampilan pra sarat tentang perkalian.

Siswa dapat membulatkan 72 ke dalan bilangan puluhan yaitu 70 , tetapi diantara mereka banyak yang mengalami kesulitan menentukan hasil perkalian dari $8 \times 9$. Setelah kegiatan pembelajaran selesai peneliti membagikan angket pada siswa, bersamaan dengan itu guru juga mengadakan wawancara dengan guru kelas IV. Dari hasil wawancara diketahui bahwa guru kelas IV mengeluh merasa sulit dalam menyajikan pembelajaran matematika tentang perkalian.

Selama ini yang ia lakukan dalam materi perkalian tentang menghafal perkalian sampai bilangan 100 adalah: siswa disuruh menghafal perkalian sampai bilangan 100 yang sudah hafal maju satu persatu ke depan, sedangkan yang belum hafal akan dihukum tidak boleh istirahat. Namun demikian mereka masih banyak yang belum hafal. Dari hasil angket yang disebar pada 40 siswa kelas IV menunnjukan bahwa 18 siswa tidak menyukai pelajaran matematika, artinya $45 \%$ dari siswa tidak menyukai pelajaran matematika, 13 siswa atau $32,5 \%$ dari siswa memilih biasa-biasa saja, dan 9 siswa atau $22,5 \%$ menyatakan menyukai matematika.

Rata-rata mereka tidak menyukai matematika karena mereka sulit mengikutinya. Pada tanggal 16 September 2016 peneliti mengadakan diskusi dengan guru kelas IV dan teman sejawat untuk membicarakan persiapan pelaksanaan tindakan penelitian.

Dari hasil diskusi disepakati, peneliti bertindak sebagai penyaji sedangkan guru kelas IV dan teman sejawat bertindak sebagai observer atau pengamat. Kegiatan dilanjutkan dr $\mathrm{dmm}^{-\cdots}$ menyiapkan peralatan, menyusun si 141 menyusun persiapan pembelajaran, men: instrumen, dan menentukan jadwal penelitian 
Pelaksanaan tindakan ini dilaksanakan pada 4 Oktober 2016, dengan bahasan menghafal perkalian dan pembagian sampai bilangan 100 , dengan waktu 2 jam pelajaran ( 80) menit. Pada bagian ini penulis sebagai penyaji dibantu oleh guru kelas IV dan teman sejawat sebagai observer. Urutan penyajian sebaagai berikut:

Pada bagian ini akan disajikan pembahasan dari analisa data sebagai hasil dari observasi guru kelas IV dan teman sejawat pada siklus-1 dan siklus-2. Berdasarkan rumusan masalah yang dikemukakan pada penelitian ini, maka pembahasan ini secara urut dikemukakan sebagai berikut:

(1) Kemampuan hitung perkalian siswa kelas IV,

(2) Aktivitas siswa dalam pembelajaran,

(3) Kooperatif (kerja sama) siswa dalam menyelesaikan tugas kelompok, dan

(4) Hal-hal yang ditemukan selama tindakan siklus-1 dan siklus-2

1. Kemampuan Hitung Siswa Kelas IV

Berdasarkan analisa hasil observasi has tindakan siklus-1 dengan bahasan menghaf perkalian dan pembagian sampai deng: bilangan 100, pada pertanyaan penjajag: menunjukkan penguasaan materi sebelu tindakan dilaksanakan $31 \%$ dan setelah tindak: dilaksanakan $68 \%$.

Pada tindakan siklus-2 dengan bahas: menghitung erkalian dengan cara bersusu menunjukkan sebelum tindakan dilaksanak: penguasaan materi siswa tentang perkalic bersusun menurut hasil pertanyaan penjajagan sebesar $48 \%$ sedangkan setelah tindakan berlangsung menunjukkan $76 \%$.

Dengan target kemampuan hitung perkalian $70 \%$ maka hal ini menunjukkan bahwa pembahasan tentang perkalian dengan menggunakan media benda-benda terdekat dapat meningkatkan kemampuan hitung perkalian

Dari hasi observasi peneliti pada pembelajarn matematika dengtan bahasan membulatkan hasil operasi hitung dalam satuan, puluhan ,dan ratusan terdekat yang disampaikan oleh guru kelas IV, siswa tampak pasif, takut bertanya, dan kurang percaya diri serta perhatian mereka kecil sekali. Juga pada awal tindakan siklus-1, tampak siswa takut menjawab dan memperagakan ke depan hingga guru mengulang kegiatan awal permainan siklus-1.

Namun setelah setelah permainan selesai pada siklus pertama, aktivitas siswa meningkat, siswa menjadi semangat hal tersebut tampak ketika memperagakan permainan lompat jari mulai awal kelipatan dua dan seterusnya, siswa berebut untuk memperagakan ke depan. Begitu pula pertanyaan demi pertanyaan yang disampaikan oleh guru, ditanggapi secara aktif oleh siswa dengan hampir seluruh siswa siap menjawab pertanyaan tersebut.

Menurut hasil observasi guru kelas IV dan teman sejawat, aktivitas siswa pada tindakan siklus-1 menunjukkan: siswa aktif $54 \%$, siswa sedang $32 \%$, dan siswa pasif $14 \%$. Sedangkan pada tindakan siklus-2, siswa aktif78\%, siswa swdang $18 \%$, dan siswa pasif $4 \%$. Dengan demikian berdasar hasil analisis data diatas dapat dikatakan bahwa pembelajaran hitung perkalian dengan media benda-benda terdekat dapat meningkatkan aktivitas belajar.

Kooperatif Dalam Menyelesaikan Kerja Kelompok. Berdasarkan hasil observasi peneliti pada pembelajaran matematika yang disajikan oleh guru kelas IV, siswa tampak tidak semangat, terkesan takut, apa lagi ketika menyelesaikan tugas dari guru baik perorangan maupun kelompok, sebaian besar mereka menggantung pada teman, terutama teman sebangku. Hal ini menunjukkan bahwa interaksi antar siswa dan kerja sapa dalam kelompok belum terbentuk.

Dari hasil pengamatan guru kelas IV dan teman sejawat sat peneliti melaksanakan tindakan pada siklus-1 menunjukkan bahwa saat menyelesaikan utgas kelompok, siswa menyelesaika bersama, berpikir bersama, dan memecahkan masalah bersama. Hal tersebut tampak sekali saat memasangkan kartu-kartu bilangan ke dalam bentuk perkalian dan pembagian, mereka terlibat dalam $\mathrm{di}^{-1}$. mencari pasangan yang mudah , 142 diselesaikan.

Begitu juga pada tindakan siklus-2, mereka berkerja sama seolah suda tidak ada pembatas antara tang cepat belajar dan yang 
lambat belajar. Secara rinci hasil analisis dari observasi pada tindakan siklus-1 sebagai berikut: siswa aktif $62 \%$, siswa sedadang $28 \%$, dan siswa pasif $10 \%$. Sedangkan pada tindakan siklus-2 siswa aktif $78 \%$, siswa sedang $14 \%$ dan siswa pasif $2 \%$.

Berdasarkan analisis data hasil observasi tindakan siklus-1 dan siklus-2 serta hasil obsevasi peneliti pada pembelajaran yang disampaikan oleh guru kelas IV, keja sama pada kelompok dikatakan berhasil. Artinya, dengan menggunakan media benda-benda terdekat dalam menyelesaikan tugas bersama pembelajara matematika tentang hitung perkalian dapat mempertingi kerjasama dan interaksi antar siswa.

Hal-Hal Yang Ditemukan Dalan Observasi Tindakan Siklus-1 Dan Siklus-2 a) Motivasi semangat belajar siswa semakin tinggi, tampak saat permaina yang dilaksanakan pada tindakan siklus-1 dan siklus-2. siswa berebut untuk memperagakan permainan ke depan. Kedisiplinan siswa dalam mengikuti aturan semakin tinggi. Hal ini dapat dili hat saat siswa mengumpulkan lembar jawaban pada pertanyaan penjajagan, siswa tampak tak teratur dan makan waktu yang panjang, tetapi saat mengumpulkan lembar jawaban evaluasi baik pada siklus-1 atau siklus-2 siswatampak tertib. Selesai tindakan siklus-1 siswa bertanya kapan peneliti akan mengajar lagi di kelas IV. Hal ini menunjukkan bahwa siswa senang akan pembelajaran yang dibawakan oleh peneliti. Hasil angket juga mendukung hal yang sama, rata-rata siswa senang akan pembelajaran maatematika yang dibawakan oleh peneliti. Kreativitas siswa juga tampak saat menyelesaikan kerja kelompok. masing - masing kelompok menggunakan cara masing-masing untuk memecahkan masalah. Ada yang menggunakan pembagian tugas dan ada yang menyelesiakan bersama soal demi soal.

\section{KESIMPULAN DAN SARAN}

Berdasarkan hasil analisis data dan pembahasan tentang pembelajaran hitung perkalian dengan dengan media benda-benda terdekat pada pelajaran matematika siswa kelas IV sekolah dasar dapat disimpulkan sebagai berikut: Pembelajaran hitung perkalian dengan menggunakan media benda-benda terdekat dilaksanakan dengan urutan:

Apersepsi yang dapat berupa pertanyaan untuk membawa siswa menuju mareri atau pertanyaan penjajagan materi, Permainan jari, yang dalam hal ini pada siklus pertama dengan permainan lompat jari dan siklus kedua dengan permainan perkalian jari. Penerapan permainan pada perkalian,

Kerja kelompok, dan Evaluasi. Pembelajaran hitung perkalian pada pelajaran matematika dengan menggunakan media benda-benda terdekat meningkatkan aktivitas pembelajaran, mempertinggi interaksi antar siswa dan keja sama kelompok, serta meningkatkan pemahaman siswa terhadap perkalian dan pembagian sehingga kemampuan hitung siswa semakin tinggi. Pembelajaran matematika dengan media benda-benda terdekat memacu keberanian siswa sehingga dengan sendirinya rasa minder dan takut bagi siswa tertentu akan hilang, memotivasi siswa untuk lebih aktif dalam pembelajaraan, sehingga pembelajaran semakin hidup, dan memberikan kebebasan pada siswa untuk berkreasi dalam menyelesaikan tugas kelompok.

Sesuai dengan hasi penelitian maka sebagai tindak lanjut dan kesempurnaan maka dikemukakan saran-saran sebagai berikut: Dalam melaksanakan pembelajaran hendaknya guru mempersiapkan segala sesuatunya seperti: rencana pelaksanaan pembelajaran (RPP), lembar kerja, alat evaluasi, dan peralatan yang diperalukan. Untuk meningkatkan kemampuan hitung perkalian, aktivitas, dan kreativitas dalam pembeljaran, hendaknya guru menggunakan model pembelajaran yang menarik dan menggunakan media yang sesuai, mis ${ }^{-1 \ldots . . .}$ media benda-benda terdekat seperti 143 bilangan dan jari tangan. Untuk pene selanjutnya hendaknya diadakan perbaikanperbaikan dan penyempurnaan sehingga diperoleh hasil yan baik. 


\section{DAFTAR PUSTAKA}

Aqip, Zainal. 2003. Karya Tulis Ilmiah Bandung: Yrama Widya.

AZ, Mulyana. 2001. Rahasia Matematika. Surabaya: Edutama Mulya.

Degeng, Nyoman Sudana.1997. Strategi Pembelajaran. Malang: Ikip Malang.

Depdikbud. 2004. Kurikulum Pendidikan Dasar, Garis-garis Program Pengajaran (GBPP). Jakarta: Depdikbud.

Hamalik, Umar. 1982. Media Pendidikan.

Bandung: Alumni.

Harmini,Sri. 2004. Model Bermain Sebagai Upaya Meningkatkan Pemahaman Siswa Terhadap Operasi Penjumlahan dan
Pengurangan Bilangan Cacah Di Kelas III $S D$.

Hasil Penelitian, tidak diterbitkan : Universitas Malang.

Kamisa. 1997. Kamus Lengkap Bahasa Indonesia. Surabaya: Kartika.

Mulyasa, E. 2005. Menjadi Guru Profesional. Jakarta: Remaja Rosda Karya.

Puspita. 2004. Aneka Berhitung Cepat, tidak diterbitkan. Bandung: Dipakai untuk Kalangan Sendiri.

Wibawa, Basuki. 2000. Penelitian Tindakan Kelas. Jakarta: Direktorat Tenaga Kependidikan. 